\title{
THE RETURN OF THE JEWS FROM EXILE.
}

By W I L L I A M RAINEY HARPER, The University of Chicago.

I. When did the return take place? - We must distinguish three times and three leaders. The first was in $535 \mathrm{~B}$. C., when, under Prince Zerubbabel, a company returned and immediately laid the foundations of the second temple. The second was in 458 B. C., when a company under Ezra came up from Babylon, and the new form of the law was adopted. The third was in 445 B. C., when Nehemiah, the cup-bearer of the king, returned with a company and rebuilt the walls of Jerusalem and the gates. It is with the first return that we are concerned in this article, for the work of Haggai and Zechariah was performed at that time.

It will be remembered that the proclamation for the return was made in $536 \mathrm{~B}$. C.; that in the seventh month of the same year, the return having been made, the altar was built and sacrifices were resumed ; ${ }^{x}$ that in $535 \mathrm{~B}$. C. the foundation of the temple was laid $;^{2}$ and that for a period of fifteen years the work of rebuilding stopped. ${ }^{3}$ Cyrus dies in 529 B. C., and Cambyses, his successor, in 522 B. C.; after the brief reign of the false Smerdis, Darius Hystaspes comes to the throne in $522 \mathrm{~B}$. C. After a short time he adopts the former policy of Cyrus, and work is permitted to begin again, but the people are lukewarm.

In September, 520 B. C., Haggai preaches his first sermon (Hag. I : I-II). In the following October he preaches a second time (Hag. 2:I-9). In November Zechariah preaches his first sermon (Zech. I : I-6). In December Haggai preaches his third and fourth sermons (Hag. 2:10-19, and vss. 20-23). In January, 5 I9 B. C., Zechariah's visions are received and announced. The work on the temple having been resumed in the autumn of 520 , the temple is completed in $515 \mathrm{~B}$. C.

× Ezra 3:1-6.

2 Ibid., 3 : 10.

3 Ibid., $4: 24$. 
It will also be remembered that, according to the accounts given us, ${ }^{4}$ there returned, under the leadership of Zerubbabel, 42,360 of the people, together with 4,000 priests, 74 Levites, 7,359 slaves, 125 singers, I 39 police, and that with this company there were brought 736 horses, 245 mules, 6,270 asses, and 420 camels.

2. The bright side of the situation. - There had been seventy years of exile. This exile was, in real truth, a captivity. A people accustomed for many centuries to rule themselves are transplanted, and for nearly a century experience in a strange land the power of the greatest despotism known in history. After all this there has come liberty, and liberty, even when the circumstances are the most distressing, is prized above all other blessings. Moreover, the ancient Jews were a people whose government was essentially democratic; for it is in their history that we may find the germs of the institutions that underlie our modern republics. Liberty had now come - freedom to govern themselves within certain limits, and to take up once more a national existence.

After seventy years of despair and suffering there are now hope and joy. It is very difficult for us to appreciate in detail the severity of this suffering during the seventy years of exile, so many and so different were the factors which entered into it, so pathetic and so tragic was the whole situation. It was not physical distress, but heart-sickness, that had benumbed and paralyzed their souls. From all this there had now come a release. Hope, building upon the events of these first days, reaches far out into the future, and enthusiasm now takes the place of the death-like despair which had fallen over them through these many decades.

The God who had deserted them has now returned. Without his presence all had been dark. They now live in the sunshine of his favor. If the same thought may be expressed in different form, Israel's God was now seen to be a God whose power was not restricted within a certain territory. $\mathrm{He}$ has become the creator of the world and the Lord of history. A

4 Ezra $2: 64 \mathrm{ff}$. 
great veil has fallen from their eyes, and they see God in a new light. He has revealed himself in a way which they had not before understood. Just as Job, under the influence of the new vision given him of God, finds the basis of all his complaints and all his troubles taken away, so Israel, with the new knowledge acquired, that her Jehovah is the God of the whole world, begins to realize that she has, indeed, a mission to the world, given her by God.

Few, after all, had believed the words spoken by the prophets - words which had been repeated many times; but now these words have been fulfilled, and, after the long captivity, Israel is restored to the home-land and to the home-city; and the temple itself will soon again stand where it stood of old. The satisfaction of the faithful must have been very great. Here is the evidence of the foreknowledge of the prophets, and of the allknowledge of Jehovah. This means that the history of the present and the future is a part of that great history of the past in which, after all, Israel had so much to be proud of, in spite of the shortcomings and the grievous sins of those who had brought ruin and disgrace upon the nation.

Israel had passed through a period of shame and reproach and disgrace. As a nation she had been knocked about until she could no longer be recognized. Men had heaped reproach upon her, and the claims of her mission to the world had been received with contempt; but now the great king is inclined to do her honor. She is to be given, once more, a place among the kingdoms of the earth. Glory and prosperity await her.

For many years Israel has been scattered here and there among the nations. The distribution has been very thorough. In lands most remote her representatives have been found. The nation has been without a home. There have been no leaders to rally the scattered members of the community. All this is past. She is again united and again at home.

Jerusalem, the city of God, the holy city, has lain for many years in ruins. No Jew could ever forget Jerusalem, and no disgrace could be more difficult to bear than that which had fallen upon the ancient and sacred city of Jehovah. But now it 
is being rebuilt. What significance lies in this fact! This, indeed, means everything!

The whole situation, as even we who live today can see it, was so strange, so overwhelming, as to make men dumb with astonishment, and to lead them to weep for very joy :

When the Lord turned again the captivity of Zion,

We were like unto them that dream.

Then was our mouth filled with laughter,

And our tongue with singing:

Then said they among the nations,

The Lord hath done great things for them.

The Lord hath done great things for us ;

Whereof we are glad.

Turn again our captivity, O Lord,

As the streams in the south.

They that sow in tears shall reap in joy.

Though he goeth on his way weeping, bearing forth the seed,

He shall come again with joy, bringing his sheaves with him. (Ps. I26.)

The whole situation may be described in a single word, and this is a word which then and there took on new significance and from that time became the keyword of true religion. It was the word "deliverance," or, as in later times it is translated, the word "salvation." It was deliverance from misery and suffering and torture, to satisfaction, and contentment, and comparative ease; from reproach and scoffs and taunts, to honor, and position, and even glory; from the dungeon to liberty; from the overwhelming darkness of God's wrath to the sunshine of divine favor.

3. The dark side.- It would be better if the other side of the picture could be lost sight of, but this would not be true to the God who was directing this history. Nothing, we may persuade ourcelves, can be more distasteful to him than to have his children look at a one-sided picture, even if it be the bright side; and not even if it be a picture of him or of his work. It was this Job's friends attempted; viz., to defend God, on a platform which God himself rejected.

The glory of Israel had, after all, departed. Considered externally-and at that time no other consideration was possible- 
the return must have seemed as pathetic, almost, as the captivity itself. The vision of broken walls, of temple ruins, of confusion and chaos on every side, must have been disheartening to those pilgrims who, for so many weeks, had been traversing the desert on their homeward journey. The present Israel is only a shadow of the former, lacking in boldness and independence; lacking, above all, in high ambition. The second temple was "as nothing " 5 in the eyes of the old men who could recall Solomon's temple.

The hearts of many had become attached to the flesh-pots, not of Egypt, but of Babylonia, so that the number of those who returned was pitiably small. The result of long residence in a foreign country had been to make the people satisfied to remain. At all events, they were not courageous enough to brave the dangers and the hardships of the weary journey back to Palestine. Not all of those who failed to return were renegade Israelites; for many, doubtless, would have been glad to make the journey, if age or lack of means had not prevented; but the list, as it is given to us, was ridiculously small, and it is not difficult to understand why, with so small a number, greater things were not accomplished when the return actually took place.

Very serious was the fact that no great men were now to be found in the ranks of Israel. Zerubbabel, the prince, was a weakling; Joshua, the priest, an ordinary man. There was no Moses to organize the nation's efforts; no Joshua to lead them again to the promised land; and no David to fight their battles with hostile foes. There was, in fact, no leadership. Worse than this, there was no great and controlling purpose. Their greatest ambition was to get back; but, when once back, they had not the strength or fortitude to meet the situation as they found it.

The real truth is that their faith in God, of which they boasted so often and so strongly, was a kind of superstitious feeling that he would lift up and exalt them, come what might. Their faith was so great, forsooth, that they would leave everything to him.

5 Hag. $2: 3$. 
This meant, of course, on their part indifference and inactivity ; it was the same faith which had deadened Israel in the days of Jeremiah's preaching, but which failed to save them from the hand of Nebuchadnezzar. This so-called faith in large measure controlled them; and because it had control of them it took away from them all life and action.

Zealous enemies, likewise, were on every side. Some of these were at home; some of them at the court of the king. All alike sought in every way to hinder and obstruct the progress of the nation. That these efforts were successful appears from the fact that after the first year the building of the temple ceased for a decade and a half.

Prophecy was in its decline. In fact, it was almost dead. The national idea upon which prophecy rested is no longer in vogue "The exiles returned from Babylon to found, not a kingdom, but a church." 6 "Israel was no longer a kingdom, but a colony." 7 In fact, when, a century before, Deuteronomy had been accepted as the book of the people, the voice of the prophet was not so necessary. There was no longer a field for prophecy. Other expressions of the religious idea now become prominent; on the one hand, the priest with his ritual and his ecclesiasticism; on the other hand, the sage with his moralizing and his speculations. The work of Israel in the future was to be done through these agencies, rather than through prophecy.

4. The future for Israel.-But Israel had a future before her; her work is only half finished. Five hundred years and more lie back of her from the days of Samuel, Saul, and David. Another five hundred lie before her, to the time when her great work will have been accomplished. She stands in the very center of her long career. This future period will be more important in the history of the church and in the history of religious thought than any period that has preceded it. The day has now come for the first time when personal religion may be most easily cultivated. The time for "genuine piety" has now appeared. In this age, when the priest is supreme, there lives

${ }^{6}$ Kirk patrick.

7 George Adam Smith. 
also the psalmist; and many of the most beautiful of Israel's psalms are yet to be sung. But this work of priest and psalmist, as well as that of sage, will furnish the theme for sketches in a succeeding number.

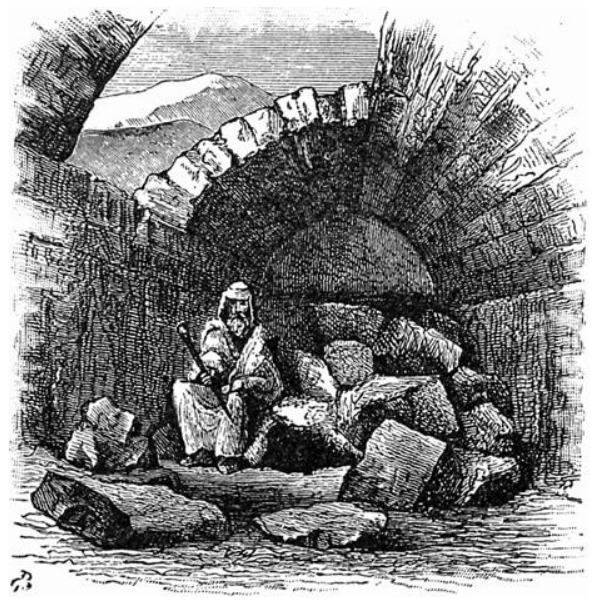

JACOB'S WELL

[From Conder and Kitchener, Survey of Western Palestine, Memoirs, Vol. II, p. 172] 